\title{
The Knowledge Management Activities for Achieving Competitive Advantage: A Conceptual Framework
}

\author{
Lew Sook-Ling ${ }^{1}$, Tan Choo-Kim ${ }^{1} \&$ Siti Fatimah Abdul Razak ${ }^{1}$ \\ ${ }^{1}$ Faculty of Information Science and Technology, Multimedia University, Malaysia \\ Correspondence: Lew Sook-Ling, Faculty of Information Science and Technology, Multimedia University, \\ Jalan Ayer Keroh Lama, 75450 Melaka, Malaysia. Tel: 60-6252-3124. E-mail: sllew@mmu.edu.my
}

Received: September 5, 2013

Accepted: October 8, $2013 \quad$ Online Published: November 15, 2013

doi:10.5539/ijbm.v8n23p1

URL: http://dx.doi.org/10.5539/ijbm.v8n23p1

\begin{abstract}
The main aim of this paper is to discover the most suitable knowledge management (KM) activities of Multimedia Super Corridor-status organisations in Malaysia (MSC Malaysia companies) in their respective situation in achieving competitive advanatge. Various KM activities from past researches since 1990 were reviewed and investigated. 25,932 articles were found using a keyword index search of "knowledge management" in the ProQuest Central online database. After topic filtering, there were only 30 articles were related to the "knowledge management activities". Based on these related topics of the 30 articles, this paper determines there are four KM activities in achieving organisational competitive advanatge: knowledge creation, storage, sharing and utilisation. These four KM activites were then empirically tested and verified using primary data collected from 600 MSC Malaysia Companies.
\end{abstract}

Keywords: knowledge management (KM), MSC Malaysia and KM activities

\section{Introduction and Issues}

Practising knowledge management (KM) activities is one of the pre-conditions of implementing KM for any organisation. However, numerious terminologies and ambiguous definitions of KM activities were recorded from academics, analysists and pratitioners since the inception of KM. Consequently, these numerious terminologies and ambiguous definitions of $\mathrm{KM}$ activities may create difficultities for KM managers or practioners to implement effective KM activities in their respective situations for organisational success. Therefore, a set of unambiguous KM activities is fundamental for KM practioners in achieving organisational success.

Malaysia, being a rapidly emerging economy is critical to understand the KM activities in order to transform its production-based economy into a knowledge-based country. Failure to adopt the relevant KM activites that can impede an organisational succes and national goals. Among the national goals, Vision 2020 envisions Malaysia becomes a developed country by 2020. To materialise the vision, in 1996, Multimedia Super Corridor (MSC) project was initiated for "the best of first-world knowledge and information technology (IT) infrastructure, at developing-nation costs" (MDeC, No date). MSC Malaysia companies have reated productive outcome for the nation such as creating a highly skilled workforce and a total of 119,138 jobs (Malaysia MDeC, 2011). Therefore, this paper is to review and discover KM activities since 1990s from past researches with the aim to identify which is the most suitable for MSC Malaysia companies to adopt in their specific situation.

The following sections of this paper will first present the literature reviews of KM, KM activites and competitive advantage. Thereafter, exisitng issues and studies surrounding $\mathrm{KM}$ activites and competitive advantage are summarised and discussed. Section 6 finally concludes this paper.

\section{Literature Review}

\subsection{Knowledge Management (KM)}

The definitions of knowledge were often debated by practitioners, researchers and analysts (Tiwana, 2002; Wiig, 1997). Different viewpoints of knowledge direct to multiple definitions of knowledge management (KM). If knowledge is viewed as information accessibility, then KM is centred on creating and managing knowledge databases (Ngai \& Chan, 2005; Tiwana, 2002; Yaghoubi, Yazdani, Ahoorani, \& Banihashemi, 2011). Alternatively, when knowledge is viewed as an activity or a process, then the KM is centred on knowledge 
activities or processes (Alavi \& Leidner, 2001; Benbya, Passiante, \& Aissa, 2004; Davenport \& Prusak, 2000). Aditionally, when viewing knowledge as a capability, KM is centred on creating core capability, understanding the way of achieving competitive advantage, and producing intellectual capital (Abdel-Aziz \& Kamel, 2012; Ali \& Freyedon, 2011; Zack, 1999-a). These numerious conceptions of knowledge advocate that each conception of KM requires different approach to focus for managing the knowledge. Hence, different KM foci implied multi-dimensional roles of KM.

Almost all of the aspects in business activities are covered by the multi-dimensional roles of KM (Alavi \& Leidner, 2001; Wiig, 1997; Yaghoubi, et al., 2011). A KM life cycle is completed by these business activities (Benbya, et al., 2004) and the KM life cycle is a repetition process of KM activities (Benbya, et al., 2004; West \& Hess, 2002). In the context of this paper, the definitions of knowledge as ativity and capability tie in very neatly in the context of this paper as ativity relates to KM activities and capability relates to competitive advantage.

\subsection{KM Activities and Competitive Advanatge}

Past researches (Benbya, et al., 2004; West \& Hess, 2002) supported KM activity as an iterative sequence of KM activities and the KM activities are supported by IT applications (Chang \& Chuang, 2011; Sher \& Lee, 2004; Wang, Klein, \& Jiang, 2007). Leonard-Barton (1995) noted "Core capabilities constitute a competitive advantage for a firm; they have been built up over time and cannot be easily imitated". When competitive advantage is achieved, an organisation is able to attain a differentiation position (Porter, 1985). This position is exploited by using a unique blend of activities (Prior, 2006), which are capabilities of maintenance and enhancement of its competitive marketplace. As a result of these notations, KM activities, IT applications and core capabilities are further investigated to ensure their stability to achieve competitive advantage.

Past researchers have agreed that knowledge creation, sharing, storing and utilisation are the main components of competitive advantage of multinational corporations (Fransson, Hakanson \& Liesch, 2011; Lee, Cho, Xu \& Fairhurst, 2010; Reijers \& Aalst, 2005). These components are KM activities (Abdel-Aziz \& Kamel, 2012; Ali \& Freyedon, 2011; Wang, et al., 2007). With KM activities, mutinatioanl corporations can combine and re-combine knowledge in reaping competitive advantage across physical locations (Reilly, Scott, \& Mangematin, 2012; Scott \& Gibbons, 2011). Therefore, in this research, capability to perform these KM activities is operationalised as reaping competitive advantage.

In order to examine the KM activities for organisational competitve advanatage, the most frequently used KM activity terminologies were identified from prominent and relevant KM studies since 1990s. A keyword index search of "knowledge management" was conducted in the ProQuest Central online database. 25,932 articles were discovered on December 2009 . Topic and field screening was first conducted and continued by updated searching on August 2013, there were only 30 articles connected to the "knowledge management activities".

Table 1. Summary of KM activities by author since 1990

\begin{tabular}{|c|c|c|c|c|c|c|c|}
\hline & Year & Author(s) & Phase 1 & Phase 2 & Phase 3 & Phase 4 & Phase5 \\
\hline 1 & 1994 & Nonaka & Socialise & Externalise & Combine & Internationalise & \\
\hline 2 & 1997 & Bassie & Create & Capture & Use & & \\
\hline 3 & 1997 & Wiig & Create & Develop & Organise & Leverage & \\
\hline 4 & 1997 & Gertjan, Rob and Eelco & Develop & Consolidate & Distribute & Combine & \\
\hline 5 & 1998 & Mayo & Create & Capture & Storage & Availability & Utilisation \\
\hline 6 & 1998 & Martinez & Capture & Organise & Share & & \\
\hline 7 & 1998 & Blake & Capture/Collect & Distribute & & & \\
\hline 8 & 1999 & Zack & Create & Manage & Utilise & & \\
\hline 9 & 1999 & Zack & Create & Explicate & Share & Apply & Improve \\
\hline \multirow[t]{2}{*}{10} & 2000 & Davenport and Prusak & Generate & Flow/Share & Establish/ & Codify & Transfer \\
\hline & & & & & Maintain & & \\
\hline 11 & 2000 & Meso and Smith & Use & Search & Create & Package & \\
\hline 12 & 2000 & Hahn and Subramani & Acquire & Organise & Communicate & & \\
\hline
\end{tabular}




\begin{tabular}{|c|c|c|c|c|c|c|c|}
\hline 13 & 2001 & Alavi and Leidner & Create & $\begin{array}{l}\text { Store/ } \\
\text { Retrieve }\end{array}$ & Transfer & Apply & \\
\hline 14 & 2001 & Kim & Create & Organise & Locate & Distribute & Share \\
\hline 15 & 2001 & $\begin{array}{l}\text { Bloodgood and } \\
\text { Salisbury }\end{array}$ & Create & Transfer & Protect & & \\
\hline 16 & 2002 & Tiwana & Acquire & Share & Utilise & & \\
\hline 17 & 2002 & $\begin{array}{l}\text { King, Peter and } \\
\text { McCoy }\end{array}$ & Capture & Store & Disseminate & & \\
\hline 18 & 2002 & Holsapple and Joshi & Acquire & Select & Internalise & Use & \\
\hline 19 & 2003 & Bose & Collect & Analyse & Exchange & Utilise & \\
\hline 20 & 2004 & $\begin{array}{l}\text { Benbya, Passiante and } \\
\text { Aissa }\end{array}$ & Generate & Store & Distribute & Apply & \\
\hline 21 & 2004 & Sher and Lee & Collect & Codify & Combine & & \\
\hline 22 & 2005 & Ngai and Chan & Create & $\begin{array}{l}\text { Acquire/ } \\
\text { Capture }\end{array}$ & Store & Maintain & Disseminate \\
\hline 23 & 2005 & Rajiv and Sanjiv & Create & Share & Utilise & & \\
\hline 24 & 2007 & Wang, Klein and Jiang & Create & Share & Store & Use & \\
\hline 25 & 2008 & $\begin{array}{l}\text { Nevo, Furneaux and } \\
\text { Wand }\end{array}$ & Create & Codify & Transfer & Apply & Feedback \\
\hline 26 & 2009 & Hester & Process & Organise & Restructure & & \\
\hline 27 & 2009 & King & Create & Acquire & Communicate & Improve & \\
\hline 28 & 2011 & Ali and Freyedon & Capture & Codify & Retrieve & Share & Leverage \\
\hline 29 & 2011 & $\begin{array}{l}\text { Yaghoubi, Yazdani, } \\
\text { Ahoorani and } \\
\text { Banihashemi }\end{array}$ & Create & Share & Apply & & \\
\hline 30 & 2012 & Abdel-Aziz and Kamel & Create & Transfer & Share & Apply & \\
\hline
\end{tabular}

Based on Table 1, numerious terminologies with different numbers of phases were used. Table 2 summarises the number of phases and found that they are mostly three and four.

Table 2. Number of phases of KM activity since 1990

\begin{tabular}{lllll}
\hline Number of Phases & 2 & 3 & 4 & 5 \\
\hline $\begin{array}{l}\text { Number of Study/Studies } \\
(\mathrm{n}=30)\end{array}$ & 1 & 11 & 11 & 7 \\
\hline
\end{tabular}

Table 3 lists $34 \mathrm{KM}$ activity terminologies used in past $\mathrm{KM}$ researches. The six most frequently used terminologies are create (17), share (10), utilise (9), capture (7), distribute (6) and store (6). 
Table 3. Terminologies of KM activity used by different authors

\begin{tabular}{|c|c|c|}
\hline & Terminology & Frequency of Usage \\
\hline 1 & Acquire & 5 \\
\hline 2 & Analyse & 1 \\
\hline 3 & Apply & 6 \\
\hline 4 & Availability & 1 \\
\hline 5 & Capture & 7 \\
\hline 6 & Codify & 4 \\
\hline 7 & Collect & 2 \\
\hline 8 & Combine & 3 \\
\hline 9 & Communicate & 2 \\
\hline 10 & Consolidate & 1 \\
\hline 11 & Create/Generate & 17 \\
\hline 12 & Develop & 2 \\
\hline 13 & Distribute / Disseminate & 6 \\
\hline 14 & Exchange & 1 \\
\hline 15 & Explicate & 1 \\
\hline 16 & Externalise & 1 \\
\hline 17 & Feedback & 1 \\
\hline 18 & Improve & 2 \\
\hline 19 & Internalise & 1 \\
\hline 20 & Internationalise & 1 \\
\hline 21 & Leverage & 2 \\
\hline 22 & Locate & 1 \\
\hline 23 & Maintain & 2 \\
\hline 24 & Manage & 1 \\
\hline 25 & Organise & 4 \\
\hline 26 & Package & 1 \\
\hline 27 & Protect & 1 \\
\hline 28 & Search/Retrieve & 2 \\
\hline 29 & Select & 1 \\
\hline 30 & Share & 10 \\
\hline 31 & Socialise & 1 \\
\hline 32 & Store & 6 \\
\hline 33 & Transfer & 5 \\
\hline 34 & Utilise & 9 \\
\hline
\end{tabular}

Different terminologies have recorded by different authors as listed in Table 1. However, most of them are synonyms and share common meanings.

\subsection{Theoretical Context and Conceptual Framework}

\subsubsection{Creating Knowledge}

Creating knowledge is to generate new knowledge from existing data, information and knowledge (Ali \& Freyedon, 2011). New knowledge creation involves all individuals. While the new knowledge is being developed by the individuals, the knowledge is articulated and amplified by the organisations (Nonaka, 1994). 
Teams of individuals will continue the knowledge creation by organisational learning (Nonaka, 1994; Quinn, Anderson, \& Finkelstein, 1996).

A knowledge framework for managing organisational knowledge creation process was suggested by Nonaka (1994). Knowledge creation and information processing were viewed as knowledge management (KM) activities that could process information and create knowledge in a dynamic environment of an organisation. Nonaka's (1994) study advocated socialisation, externalisation, combination and internalisation of dynamic knowledge creation for Japanese manufacturing organisations. This framework also demonstrated exchange of tacit and explicit knowledge from sustainability, complementary and combination of interaction between individuals.

Sher and Lee's (2004) study of knowledge creation incorporated managerial and organisational customs. Their findings revealed that the use of IT applications facilitated knowledge creation. Besides, IT applications also facilitated other KM activities: knowledge storage, sharing and utilisation. In another word, with effective IT applications, knowledge creation is facilitated and KM activities are optimised.

Echoing the view of Nonaka (1994), Rajiv and Sanjiv (2005) recognised the contributions of individuals and organisations in knowledge creation. They further highlighted the value of knowledge sharing in the knowledge creation. Knowledge creation is the first activity before knowledge can be shared and utilised.

In Ali and Freyedon's (2011) framework, creating knowledge would allow organisations to reveal suitable knowledge to face new challenges. This framework suggested the organisations need to store a variety of forms of data to generate different types of new knowledge later. Hence, knowledge creation is from capturing, codifying, retrieving, sharing and leveraging new and prior knowledge of the organisation. The knowledge creation is possible only with supportive IT applications.

Buiding on these conceptions, the following hypothesis is conceptualised:

H1: The more IT applications, the more knowledge creation and the higher organisational competitive advantage.

\subsubsection{Storing Knowledge}

Knowledge is an element to be recorded for subsequent need and usage (Zack, 1999-a). However, in the process of creating knowledge, organisations also forget (Alavi \& Leidner, 2001). Therefore, a way to retain organisational competitive advantage is to remember and utilise their knowledge at the right time and place.

Many researches emphasized the value of storing knowledge for organisational competitive advantage (Alavi \& Leidner, 2001; Gertjan, Rob, \& Eelco, 1997; Sher \& Lee, 2004; Wang, et al., 2007; Zehrer, 2011). Gertjan, et al. (1997) presented a framework to relate corporate memories learning in organisations. The goal of this paper was to clarify how a corporate memory which is an IT application would be used to enhance learning process. Findings revealed that any piece of knowledge that contributed to organisational competiveness could or should be saved in the corporate database. These stored databases included knowledge of products, customers, production processes, marketing and strategic plans, financial results, and, organisational vision.

Sher and Lee (2004) supported that more emphases should on knowledge creation and storage. This was because effective way of knowledge storage with high IT application usage reduced IT application costs which constituted an important aspect of organisational competitive advantage.

Zehrer (2011) demonstrated a KM model for Austrian tourism organisations. The findings supported IT applications such as corporate portals can effectively store organisational knowledge and the increased use of IT applications such as electronic newsletters, e-mail and discussion forums bring positive impacts on organisational knowledge. Organisational knowledge such as expert's experience and information needs to be recoreded and saved in readable structure for future ease of use. For instance, intranet of tourism organisation could save organisational data, information and knowledge that could be retrieved by employees for later use.

Buiding on these conceptions, the following hypothesis is conceptualised:

H2: The more IT applications, the more knowledge storage and the higher organisational competitive advantage.

\subsubsection{Sharing Knowledge}

Knowledge sharing is the phase between knowledge creation and knowledge utilisation of knowledge management (KM) activities (Abdel-Aziz \& Kamel, 2012; Becerra-Fernandez, Gonzalez, \& Sabherwal, 2004; Gertjan, et al., 1997; Rajiv \& Sanjiv, 2005; Tiwana, 2002; Wang, et al., 2007; Yaghoubi, et al., 2011). Each 
phase may position concurrently to support each other.

Becerra-Fernandez, et al. (2004) advocated that knowledge sharing was the phase of sharing tacit or explicit knowledge among individuals. There were three important claims. First, knowledge sharing meant effective dissemination, the knowledge receivers received the knowledge being disseminated and understood it well. Second, the shared knowledge could not be misunderstood by recommendations based on the knowledge. Third, there was no limitation of the recipients. The recipients could be across individuals, groups, departments or organisations. This means that knowledge sharing enabled knowledge, skills and experience intra or inter-organisationally.

The shared knowledge improved learning and allowed intra or inter-organisational members possible. Hence, the organisation member can be more responsive and interative in dynamic environment with minimal charges (Gertjan, et al., 1997; Rajiv \& Sanjiv, 2005; West \& Hess, 2002). A novice technician could handle and solve technical calls and problems with the aid of an expert system in Mocrosoft is a good example of sharing knowledge enables higher organisational competitive advanatge (Tiwana, 2002).

Buiding on these conceptions, the following hypothesis is conceptualised:

H3: The more IT applications, the more knowledge sharing and the higher organisational competitive advantage.

\subsubsection{Utilising Knowledge}

Knowledge utilisation is the phase of actual knowledge usage. The knowledge can be utilised to target strategic direction and to enhance organisational competitiveness (Wang, et al., 2007). Learning was incorporated into the organisation by utilising knowledge (Tiwana, 2002). Pervasive and wide availability of knowlegde throughout the organisation could be utilised in any scenarios. The example of an expert system helping an inexperienced and new technician to solve tehnical calls in service centre is a good example of knowledge sharing and utilisation concurrently.

Lately, KM literatures proposed that IT applications have added value to organisations by utilising knowledge organisational resources (Ali \& Freyedon, 2011; Nevo, Furneaux, \& Wand, 2008; Wang, et al., 2007). As a result, a knowledge-based organisation must utilise knowledge effectively and efficiently to confront to environmental rapid change.

As high utilisation of IT applications drives to IT application cost minimisation, effective knowledge utilisation will be an good approach for achieving competitive advantage. Due to this, knowledge, like any other resources, demands good utilisation.

Buiding on these conceptions, the following hypothesis is conceptualised:

H4: The more IT applications, the more knowledge utilisation and the higher organisational competitive advantage.

As a result the Hypotheses 1 to 4, Figure 1 depicts the proposed research framework. 


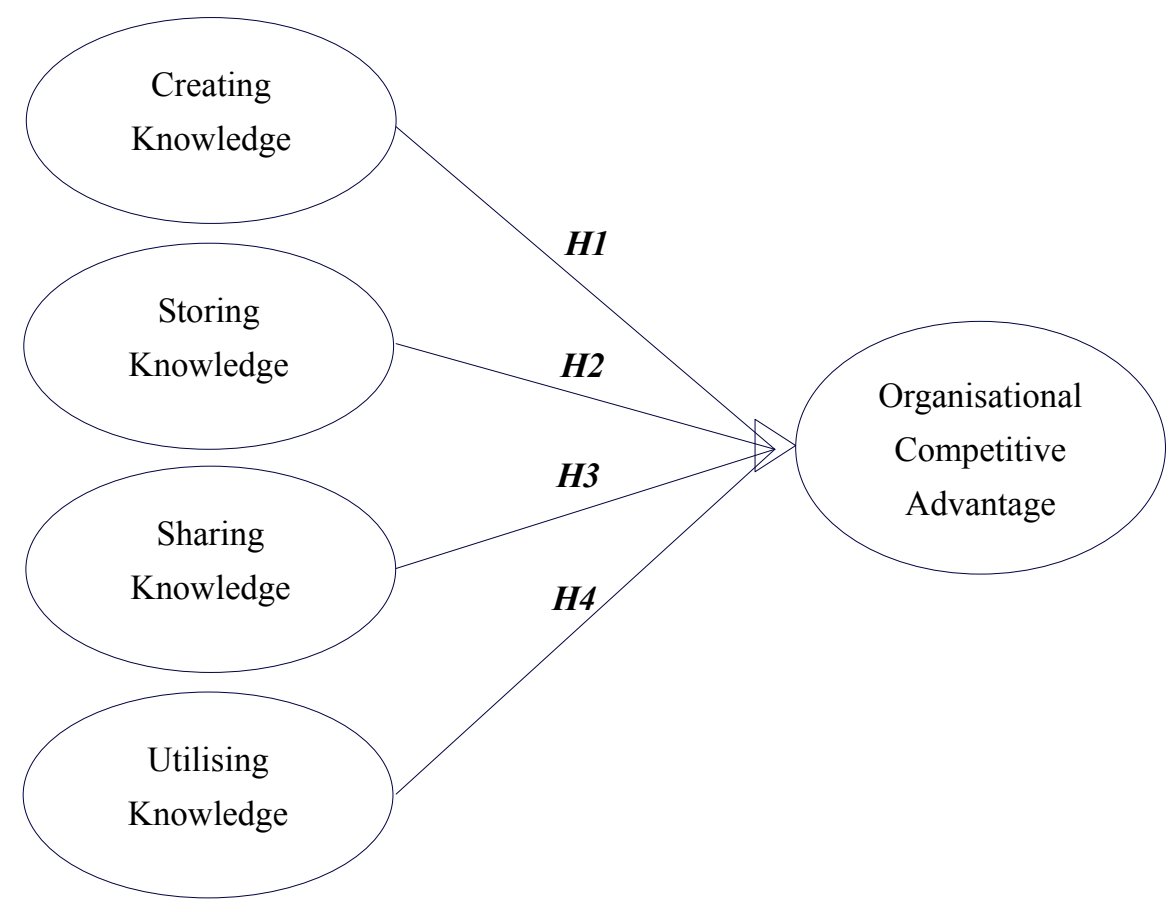

Figure 1. Conceptual framework

\section{Research Method}

Relevant prior researches, pilot test and experts' reviews were conducted to derive a set of survey questionnaire for primary data collection. A selected group of 50 managers of MSC Malaysia companies was pilot tested. The 50 respondents in pilot test met the minimum requirement of 25 (Cooper \& Schindler, 2011). Hence, content validity was verified and all the items comprised the respective independent variables that encompassed all of the main characteristics. The industry and academic experts in KM also assessed and reviewed the questionnaire for content validity. In final survey, 600 MSC Malaysia companies were selected from a list obtained from MSC Malaysia website as of $15^{\text {th }}$ January 2008 (www.mscmalaysia.com.my) using simple random sampling without replacement. The six hundred organisations were contacted using emails and follow-up phone calls from July 2008 to February 2009. 302 questionnaires (50.3\%) were returned by the respondents. Listwise deletion of cases is used to treat the missing data; leaving 295 questionnaires (49.2\%) for analysis.

We adhered strictly to wording, planning and general appearance of questionnaire design (Sekaran, 2003). Good questionnaire design principles were identified and incorporated in questionnaire to minimise response biases and measurement problems.

An 18-item KM actitivities for achieving competitve advantage were adopted based on past studies. From the 18 items, 14 (KMA1 to KMA14) were adapted from Bixler's (2000) study as significant value contributors from KM activities. Four additional items were added in the context of responsiveness and flexibility (KMA15) (Bhatt, Emdad, Roberts, \& Grover, 2010; Chang \& Chuang, 2011; Tallon, 2008; Wang, et al., 2007), products/services quality (KMA16) (Nilsson, Johnson, \& Gustafsson, 2001; Reed, Lemak, \& Mero, 2000), product development life cycle (KMA17) (Alting \& Jogensen, 1993; Dunk, 2004) and decision making process (KMA18) (Perera, 2012; Tseng, 2010) due to the unavailability in Bixler's study. Table 4 shows the list of items used in this paper. 
Table 4. List of items used

\begin{tabular}{|c|c|c|}
\hline Variable & Item & Description \\
\hline \multirow{5}{*}{$\begin{array}{l}\text { Creating } \\
\text { Knowledge }\end{array}$} & KMA1 & Stimulation and motivation of employees. \\
\hline & KMA2 & Better on-the-job training for employees. \\
\hline & KMA3 & Enhanced enterprise innovation and creativity. \\
\hline & KMA4 & Improved overall enterprise performance. \\
\hline & KMA5 & Development of an entrepreneurial culture for enterprise growth and success. \\
\hline \multirow{3}{*}{ Sharing Knowledge } & KMA6 & Improved employee retention. \\
\hline & KMA7 & Enhanced transfer of knowledge from one employee to another. \\
\hline & KMA8 & Better methods for enterprise-wide problem solving. \\
\hline \multirow{3}{*}{ Storing Knowledge } & KMA9 & Formalised knowledge transfer system (Best practices, lessons learned). \\
\hline & KMA10 & Enhanced client relations - better client interaction. \\
\hline & KMA11 & Means to identify industry best practices. \\
\hline \multirow{7}{*}{ Utilising Knowledge } & KMA12 & Improved ability to sustain a competitive advantage. \\
\hline & KMA13 & Enhanced business development and the creation of enterprise opportunities. \\
\hline & KMA14 & Enhanced and streamlined internal administrative processes. \\
\hline & KMA15 & Improved responsiveness and flexibility. \\
\hline & KMA16 & Improved products/services quality. \\
\hline & KMA17 & Improved product development life cycle. \\
\hline & KMA18 & Expedite the decision making process. \\
\hline
\end{tabular}

\section{Data Analysis and Findings}

We will apply descriptive analysis and structural equation modelling (SEM) in this research to examine the relationships between key constructs in the proposed conceptual framework as presented in Figure 1. However, the latent constructs were assessed using factor analysis by PCA with varimax rotation using SPSS version 16.0 as preliminary analysis.

\subsection{Principal Component Analysis (PCA) for Key Constructs}

Garson (1998) proposed the traditional tests such as factor analysis for structural equation modelling (SEM). Recent researchers have demonstrated the benefits of using factor analysis before SEM as complementary to theory in specifying the appropriate factor loadings in the measurement model (Lau, 2008; Teoh, 2008; Tong, 2007).

The output of "Rotated Component Matrix" for these four constructs is 82.28. It met the minumum requirement of "Kaiser-Meyer-Olkin (KMO) Measure of Sampling Adequacy (MSA)" of "above 50.00" for overall MSA with Bartlett's Test significant. Hence, in this research, with the output of MSA passed the minumum requirement, factor analysis verified that the data of the four constructs are acceptable in their distributional properties. Table 5 presents the rotated component matrix output of the survey. Based on the literature findings in Tables 1, 2 and 3, creating, storing, sharing and utilising knowledge were accepted in this paper to represent the numerious terminologies of KM activities. 
Table 5. The rotated component matrix ${ }^{\mathrm{a}}$

\begin{tabular}{|c|c|c|c|c|}
\hline & \multicolumn{4}{|c|}{ Component } \\
\hline & 1 & 2 & 3 & 4 \\
\hline \multicolumn{5}{|c|}{ Construct } \\
\hline \multicolumn{5}{|c|}{ Creating Knowledge } \\
\hline KMA1 & 0.883 & & & \\
\hline KMA4 & 0.876 & & & \\
\hline KMA3 & 0.852 & & & \\
\hline KMA5 & 0.821 & & & \\
\hline KMA2 & 0.731 & & & \\
\hline \multicolumn{5}{|l|}{ Storing } \\
\hline \multicolumn{5}{|c|}{ Knowledge } \\
\hline KMA6 & & 0.901 & & \\
\hline KMA8 & & 0.835 & & \\
\hline KMA7 & & 0.754 & & \\
\hline \multicolumn{5}{|l|}{ Sharing } \\
\hline \multicolumn{5}{|c|}{ Knowledge } \\
\hline KMA10 & & & 0.921 & \\
\hline KMA9 & & & 0.833 & \\
\hline KMA11 & & & 0.821 & \\
\hline \multicolumn{5}{|l|}{ Utilising } \\
\hline \multicolumn{5}{|c|}{ Knowledge } \\
\hline KMA16 & & & & 0.911 \\
\hline KMA14 & & & & 0.901 \\
\hline KMA13 & & & & 0.835 \\
\hline KMA15 & & & & 0.824 \\
\hline KMA12 & & & & 0.778 \\
\hline KMA18 & & & & 0.756 \\
\hline KMA17 & & & & 0.723 \\
\hline
\end{tabular}

Note: ${ }^{\text {a }}$ Rotation converged in 4 iterations.

Extraction method: Principal Component Analysis. Rotation method: Varimax with Kaiser Normalisation.

\subsection{Confirmatory Factor Analysis (CFA)}

Researcher has control power over the specification of indicators for each construct. Hence, any perceived theory needs to be validated and supported by statistical results. Confirmatory factor analysis (CFA) is the statistical approach that plays the role of confirmation to either "reject" or "accept" the perceived theory based on measurement scales (Hair, Black, Babin, \& Anderson, 2010). CFA will be used to validate the theoretical framework of this paper.

\subsection{General Guidelines for Fit Indices}

Two absolute indices, two incremental indices, associated Degree of Freedom (DF) and Model Chi-square $\left(X^{2}\right)$ values were selected to report the acceptability of the perceived theoretical framework in this paper (Niels, 2008). The two incremental indices were Goodness of Fit Index (GFI > 0.90) and Adjusted GFI (AGFI > 0.80) and the two absolute indices selected were Relative $X^{2} /$ Degree of Freedom (DF) $(\mathrm{CMIN} / \mathrm{DF}<3.0)$ and Comparative Fit Index (CFI > 0.90) (Hair, et al., 2010).

A final measurement model will be developed from an initial model of measurement via a revision process. The revision process will be conducted by omitting offending indicator(s)/construct(s) based on the acceptable fit indices listed in the previous paragraph. Indicator(s) and contruct(s) will be omitted/dropped if the acceptable fit indices are poor (not meeting the minimum score). On top of the acceptable level, some principles of guidelines will also be implemented such as "deleting only one offending indicator at a time" and "maintaining at least three indicator per construct" (Hair, et al., 2010) in this research. Relationships between constructs will then be estimated by correlational relationships between constructs. 


\section{Implications and Conclusion}

The exisitng studies and literatures on effective KM activities for achieving organisational competitive advantage are still relatively scarce especially in Malaysia. This study serves as one of its kind to identify which KM activities can reap organisational competitive advantage in Malaysian context. The significant findings of this paper will provide new information in terms of filling the gaps through a clear full chain of KM activities connecting organisational competitive advantage, primarily for MSC Malaysia companies.

From a practitioner's point of view, an IT application that enables KM activities should be prioritised than the one without. The research instruments developed in the study could also be implemented by IT application designers and programmers in designing and developing their IT applications. It could be used as a means or guide to gather preliminary data to predict the success of an IT application.

This study on the MSC Malaysia organisations would serve as guidelines to other organisations in other industries on the core KM activities for organisational competitive advantage.

\section{References}

Abdel-Aziz, A. S., \& Kamel, M. H. (2012). The Impact of Organizational Information on Knowledge Management Practices. International Journal of Business and Social Science, 3(24), 121-126.

Alavi, M., \& Leidner, D. E. (2001). Review: Knowledge management and knowledge management systems: conceptual foundations and research issues. MIS Quarterly, 25(1), 1-30. http://dx.doi.org/10.2307/3250961

Ali, A. A., \& Freyedon, A. (2011). The role of Knowledge Management in Business Performance Improvement. Interdisciplinary Journal of Contemporary Research In Business, 3(7), 560-567.

Alting, D. L., \& Jogensen, D. J. (1993). The Life Cycle Concept as a Basis for Sustainable Industrial Production. $\begin{array}{lllll}\text { CIRP Annals-Manufacturing } & \text { Technology, }\end{array}$ http://dx.doi.org/10.1016/S0007-8506(07)62417-2

Becerra-Fernandez, I., Gonzalez, A., \& Sabherwal, R. (2004). Knowledge Management: Challenges, Solutions, and Technologies. New Jersey: Pearson Education, Inc.

Benbya, H., Passiante, G., \& Aissa, B. N. (2004). Corporate portal: a tool for knowledge management synchronization. International Journal of Information Management, 24(3), 201-220. http://dx.doi.org/10.1016/j.ijinfomgt.2003.12.012

Bhatt, G., Emdad, A., Roberts, N., \& Grover, V. (2010). Building and leveraging information in dynamic environments: The role of IT infrastructure flexibility as enabler of organizational responsiveness and competitive advantage. Information \& Management, 47, 341-349. http://dx.doi.org/10.1016/j.im.2010.08.001

Chang, T. C., \& Chuang, S. H. (2011). Performance implications of knowledge management processes: Examining the roles of infrastructure capability and business strategy. Expert Systems with Applications, 38(5), 6170-6178. http://dx.doi.org/10.1016/j.eswa.2010.11.053

Cooper \& Schindler. (2011). Business Research Methods (11th ed.). New York: McGraw Hill.

Davenport, T. H., \& Prusak, L. (2000). Working Knowledge (Book Review) (Vol. 31).

Dunk, A. S. (2004). Product life cycle cost analysis: the impact of customer profiling, competitive advantage, and quality of IS information. Management Accounting Research, 15(4), 401-414. http://dx.doi.org/10.1016/j.mar.2004.04.001

Fransson, A., Hakanson, L., \& Liesch, P. W. (2011). The underdetermined knowledge-based theory of the MNC. Journal of International Business Studies, 42(3), 427-435. http://dx.doi.org/10.1057/jibs.2011.6

Garson, D. G. (1998). Structural equation modelling. Retrieved September 11, 2007, from http://www2.chass.ncsu.edu/garson/pa765/structur.htm

Gertjan, V. H., Rob, V. D. S., \& Eelco, K. (1997). Corporate memories as a tool for knowledge management. Expert Systems with Applications, 13(1), 41-54. http://dx.doi.org/10.1016/S0957-4174(97)00021-3

Hair, J. F., Black, W. C., Babin, B. J., \& Anderson, R. E. (2010). Multivariate Data Analysis-A Global Perspective (7th ed.). New Jersey: Pearson Prentice Hall.

Lau, S. H. (2008). An Empirical Study of Students' Acceptance of Learning Objects. Multimedia University, Melaka. 
Lee, H., Cho, J. J., Xu, W., \& Fairhurst, A. (2010). The influence of consumer traits and demographics on intention to use retail self-service checkouts. Marketing Intelligence and Planning, 28(1), 13. http://dx.doi.org/10.1108/02634501011014606

Leonard-Barton, D. (1995). Wellsprings of knowledge-Building and sustaining the sources of innovation. Boston, MA: Harvard Business School Press.

Malaysia MDeC. (2011). MSC Malaysia Annual Industry Report 2011. Cyberjaya: Multimedia Development Corporation Sdn. Bhd. (MDeC).

MDeSC. (2013). Why Malaysia-Quick Facts 1996-2008. Retrieved April 10, 2013, from http://www.mscmalaysia.my/technology

Nevo, D., Furneaux, B., \& Wand, Y. (2008). Towards an evaluation framework for knowledge management systems. Information Technology and Management, 9(4), 233-249. http://dx.doi.org/10.1007/s10799-007-0023-9

Ngai, E. W. T., \& Chan, E. W. C. (2005). Evaluation of knowledge management tools using AHP. Expert Systems with Applications, 29(4), 889-899. http://dx.doi.org/10.1016/j.eswa.2005.06.025

Niels, J. B. (2008). Introduction to Structural Equation Modelling Using SPSS and AMOS. London: SAGE Publications Ltd.

Nilsson, L., Johnson, M. D., \& Gustafsson, A. (2001). The impact of quality practices on customer satisfaction and business results: product versus service organizations. Journal of Quality Management, 6(1), 5-27. http://dx.doi.org/10.1016/S1084-8568(01)00026-8

Nonaka, I. (1994). A Dynamic Theory of Organizational Knowledge Creation. Organization Science, 5(1), 14-37. http://dx.doi.org/10.1287/orsc.5.1.14

Perera, U. (2012, January 13-15). Decision making delays with regard to IT investments. Paper presented at the 2012 International (Spring) Conference on Asia Pacific Business Innovation and Technology Management, APBITM 2012, Pattaya, Thailand.

Porter, M. E. (1985). Competitive Advantage: Creating and Sustaining Superior Performance. New York: Free Press.

Prior, V. (2006, December). Competitive Intelligence Terminology Glossary. Retrieved October 11, 2010, from http://www.markintell.com/language-business-intelligence/

Quinn, J. B., Anderson, P., \& Finkelstein, S. (1996). Managing professional intellect: making the most of the best. Harvard Business Review, 74(2), 71-82.

Rajiv, S., \& Sanjiv, S. (2005). Knowledge Management Using Information Technology: Determinants of Short-Term Impact on Firm Value. Decision Sciences, 36(4), 531-567. http://dx.doi.org/10.1111/j.1540-5414.2005.00102.x

Reed, R., Lemak, D. J., \& Mero, N. P. (2000). Total quality management and sustainable competitive advantage. Journal of Quality Management, 5(1), 5-16. http://dx.doi.org/10.1016/S1084-8568(00)00010-9

Reijers, H. A., \& Aalst, W. M. P. (2005). The effectiveness of workflow management systems: Predictions and lessons learned. International Journal of Information Management, 25(5), 458-472. http://dx.doi.org/10.1016/j.ijinfomgt.2005.06.008

Reilly, M., Scott, P., \& Mangematin, V. (2012). Alignment or independence? Multinational subsidiaries and parent relations. The Journal of Business Strategy, 33(2), 4-11. http://dx.doi.org/10.1108/02756661211206690

Scott, P., \& Gibbons, P. T. (2011). Emerging threats for MNC subsidiaries and the cycle of decline. The Journal of Business Strategy, 21(1), 34-41. http://dx.doi.org/10.1108/02756661111100300

Sekaran, U. (2003). Research Methods for Business: A Skill Building Approach (4th ed.). New Jersey: John Wiley \& Sons, Inc.

Sher, P. J., \& Lee, V. C. (2004). Information technology as a facilitator for enhancing dynamic capabilities through knowledge management. Information \& Management, 41(8), 933-945. http://dx.doi.org/10.1016/j.im.2003.06.004

Tallon, P. P. (2008). Inside the adaptive enterprise: an information technology capabilities perspective on business process agility. Inf Technol Manage, 9(1), 21-36. http://dx.doi.org/10.1007/s10799-007-0024-8 
Teoh, K. K. (2008). An Empirical Study of the Impact of Presence and Para Social Presence on Trust in Online Virtual Electronic Commerce. Multimedia University, Melaka.

Tiwana, A. (2002). The knowledge management toolkit: orchestrating IT, strategy, and knowledge platforms. (2nd ed.). New Jersey: Prentice Hall PTR.

Tong, Y. K. (2007). An Empirical Study of E-Recruitment Technology Adoption in Malaysia: Assessment of A Modified Technology Acceptance Model. Multimedia University, Melaka.

Tseng, M. L. (2010). An assessment of cause and effect decision-making model for firm environmental knowledge management capacities in uncertainty. Environmental Monitoring and Assessment, 161(1-4), 549-564. http://dx.doi.org/10.1007/s10661-009-0767-2

Wang, E., Klein, G., \& Jiang, J. J. (2007). IT Support in Manufacturing Firms for a Knowledge Management Dynamic Capability Link to Performance. International Journal of Production Research, 45(11), 2419-2434. http://dx.doi.org/10.1080/00207540601020437

West, J. L. A., \& Hess, T. J. (2002). Metadata as a knowledge management tool: supporting intelligent agent and end user access to spatial data. Decision Support Systems, 32(3), 247-264. http://dx.doi.org/10.1016/S0167-9236(01)00102-6

Wiig, K. M. (1997). Knowledge Management: An Introduction and Perspective. The Journal of Knowledge Management, 1(1), 6-14. http://dx.doi.org/10.1108/13673279710800682

Yaghoubi, N., Yazdani, B. O., Ahoorani, N., \& Banihashemi, S. A. (2011). Information technology infrastructures and knowledge management: Towards organizational excellence. Computer and Information Science, 4(5), 20-27. http://dx.doi.org/10.5539/cis.v4n5p20

Zack, M. H. (1999a). Developing a Knowledge Strategy. California Management Review, 41(3), 125-145.

Zehrer, A. (2011). Knowledge management in tourism-the application of Grant's knowledge management model to Austrian tourism organizations. Tourism Review of AIEST-International Association of Scientific Experts in Tourism, 66(3), 50-64.

\section{Copyrights}

Copyright for this article is retained by the author(s), with first publication rights granted to the journal.

This is an open-access article distributed under the terms and conditions of the Creative Commons Attribution license (http://creativecommons.org/licenses/by/3.0/). 